\title{
Dramatic increase in gene mutational burden after transformation of follicular lymphoma into $\mathrm{TdT}^{+}$B-lymphoblastic leukemia/lymphoma
}

\author{
Jonathan P. Belman, ${ }^{1}$ Wenzhao Meng, ${ }^{1}$ Hong Yi Wang, ${ }^{1}$ Jie $\mathrm{Li}^{2}{ }^{2}$ \\ Honore T. Strauser, ${ }^{1}$ Aaron M. Rosenfeld, ${ }^{1}$ Qian Zhang, ${ }^{1}$ Eline T. Luning Prak, ${ }^{1}$ \\ and Mariusz Wasik ${ }^{1}$ \\ ${ }^{1}$ Hospital of the University of Pennsylvania, Philadelphia, Pennsylvania 19104, USA; ${ }^{2}$ Fox Chase Cancer Center,
Philadelphia, Pennsylvania 19111, USA
}

Correspondence: wasik@ pennmedicine.upenn.edu

(C) 2020 Belman et al. This article is distributed under the terms of the Creative Commons

Attribution-NonCommercial License, which permits reuse and redistribution, except for commercial purposes, provided that the original author and source are credited.

Ontology term: hematological neoplasm

Published by Cold Spring Harbor Laboratory Press

doi:10.1101/mcs.a004614
Abstract Transformation of follicular lymphoma (FL) into B-lymphoblastic leukemia/lymphoma (B-ALL/LBL) is rare and results in greatly increased aggressiveness of clinical course. Here we present extensive molecular analysis of this unusual transformation, including immunoglobulin (lg) gene rearrangement studies, cytogenetic analysis, and whole-exome sequencing (WES) of the patient's FL, B-ALL/LBL, and normal cells. Although FL showed marked somatic hypermutation (SHM) of the Ig genes, SHM appeared to be even more extensive in B-ALL/LBL. Cytogenetically, at least three translocations were identified in the B-ALL/LBL involving the BCL2,BCL6, and MYC genes; two of these, the BCL6 and BCL2 gene rearrangements, were already seen at the FL stage. WES identified 751 singlenucleotide variants with high allelic burden in the patient's cells, with the vast majority (575) present exclusively at the B-ALL/LBL stage. Of note, a TAF3 gene mutation was shared by normal, FL, and B-ALL/LBL tissue. A KMT2D nonsense mutation was identified in both $\mathrm{FL}$ and $\mathrm{B}-\mathrm{ALL} / \mathrm{LBL}$ and therefore may have contributed directly to lymphomagenesis. Mutations in KDM6A, SMARCA4, CBX1, and JMY were specific to the B-ALL/LBL stage, possibly contributing to the B-ALL/LBL transformation. Functionally, these identified mutations may lead to dysregulation of DNA repair, transcription, and cell differentiation. Thus, these genetic changes, together with the identified chromosomal translocations, may have contributed to lymphoma development and progression. Our findings may improve the mechanistic understanding of the FL-B-ALL/LBL transformation and may have therapeutic implications for this aggressive disease.

[Supplemental material is available for this article.]

\section{INTRODUCTION}

Follicular lymphoma (FL) is the most common indolent lymphoma in the United States and Western Europe (Swerdlow et al. 2017). The clinical course is generally mild, but transformation into a more aggressive lymphoma occurs at a rate of $3 \%$ per year (Al-Tourah et al. 2008; Montoto and Fitzgibbon 2011). Most cases of FL transformation result in diffuse large B-cell lymphoma, but, rarely, lymphoblastic lesions comprised of immature rather than mature $B$ cells can arise, typically in younger patients (De Jong et al. 1988; Gauwerky et al. 1988; Kroft et al. 2000; Sun et al. 2002; Young et al. 2008). Although the mechanisms underlying 
transformation to diffuse large B-cell lymphoma have been extensively examined (Rossi et al. 2006; Pasqualucci et al. 2014), molecular characterization of the "dedifferentiation" to Blymphoblastic leukemia/lymphoma (B-ALL/LBL) has been very limited thus far (Geyer et al. 2015; Slot et al. 2016). Here we present a case of an FL transformed into B-cell B-ALL/LBL with extensive molecular characterization including analysis of the somatic hypermutation (SHM) status of the immunoglobulin (Ig) genes, cytogenetic studies, and whole-exome sequencing (WES) of the patient's normal, FL, and B-ALL/LBL tissues.

\section{RESULTS}

\section{Clinical History}

The patient was a 36-yr-old male diagnosed in June 2015 with low-grade FL based on an excisional biopsy of an enlarged right groin lymph node. A concurrent bone marrow (BM) biopsy also showed involvement of FL. The patient did not receive any chemotherapy by his own decision. In August 2016, he presented with fatigue, fevers, night sweats, and right lower extremity/groin swelling. A CT scan showed bulky, multifocal lymphadenopathy. Biopsy of the right groin lesion revealed B-lymphoblastic lymphoma. Intensive chemotherapy was initiated, but the disease progressed, including eventual appearance of circulating lymphoblasts (a leukemic phase), and the patient passed away in 2017.

\section{Histology, Immunohistochemistry, and Flow Cytometry Analysis}

The original lymph node biopsy from 2015 shown in Figure 1 displayed markedly expanded follicles, composed predominantly of small centrocytes with scattered larger centroblasts $(<5 / \mathrm{hpf}$ ). There were neither clusters nor sheets of centroblasts outside of the follicles.

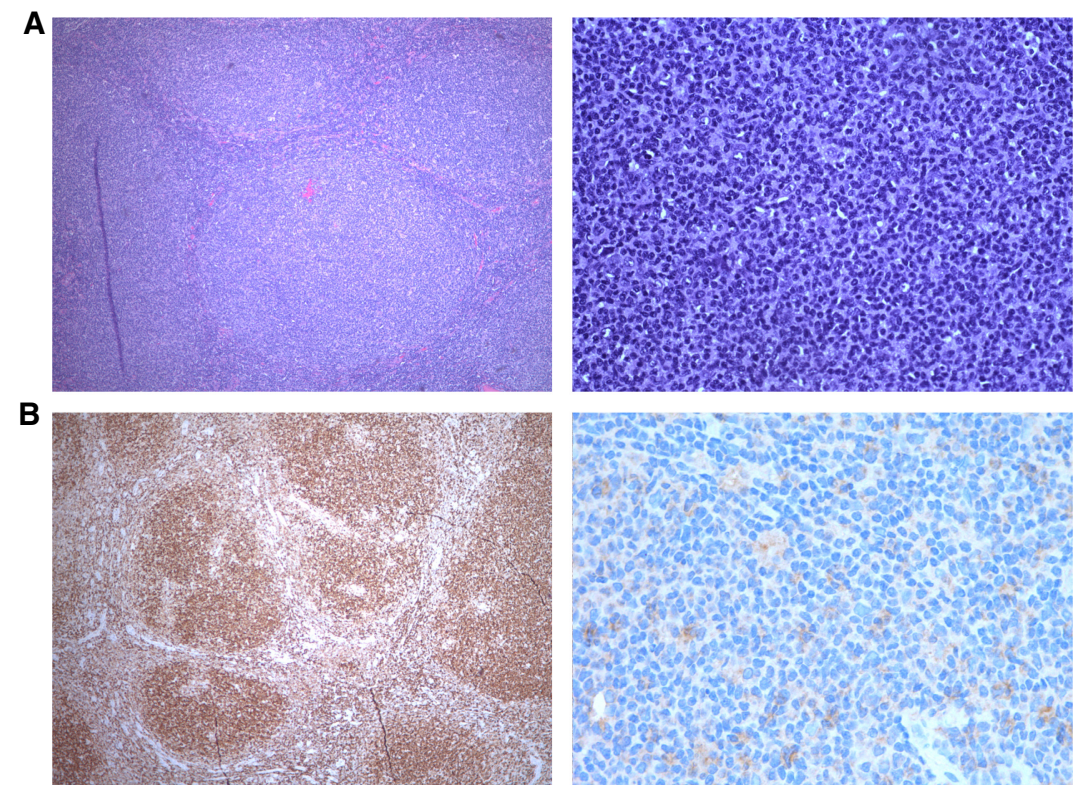

Figure 1. Tumor histopathology and immunohistochemistry of follicular lymphoma (FL). (A) Excisional biopsy of a lymph node with FL in 2015 stained for hematoxylin and eosin (magnification at 4x [upper left] and 40x [upper right]). (B) BCL2 and TdT immunohistochemical stains are shown on the lower left and lower right (magnification at $4 \times$ and $40 \times$, respectively). 

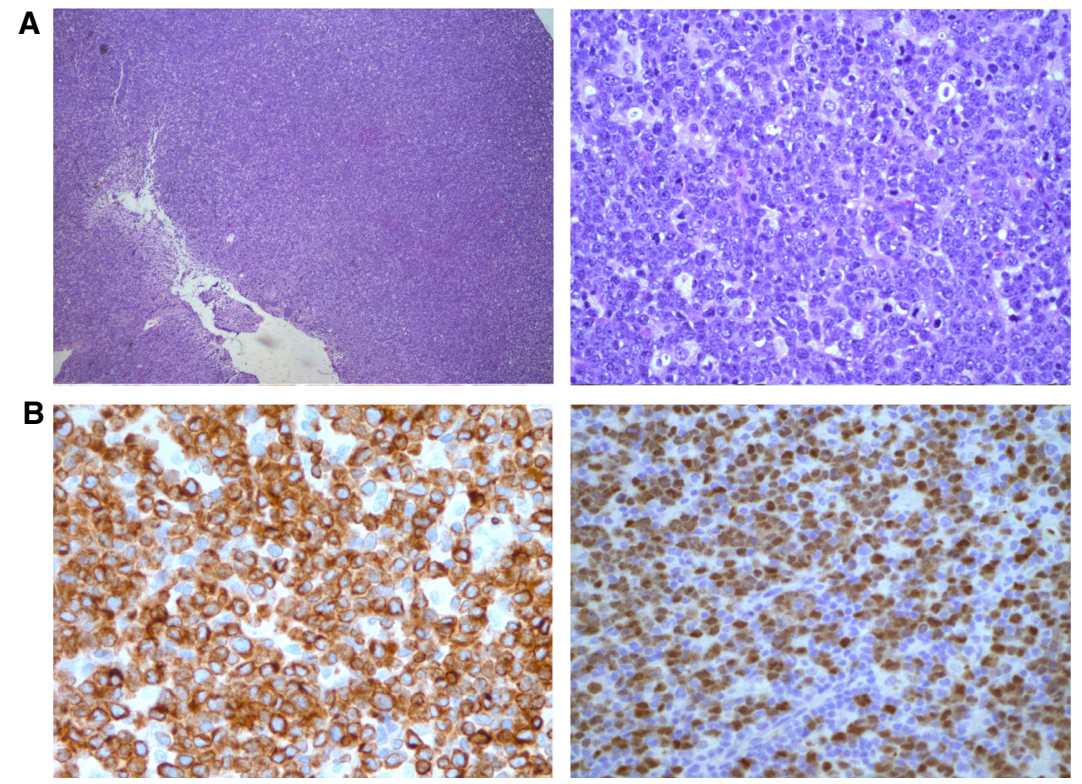

Figure 2. Tumor histopathology and immunohistochemistry of B-lymphoblastic leukemia/lymphoma (B-ALL/ LBL). (A) Excisional biopsy of a lymph node with B-ALL/LBL in 2016 stained for hematoxylin and eosin (magnification at $4 \times$ [upper left] and $40 \times$ [upper right]). (B) BCL2 and TdT immunohistochemical stains are shown on the lower left and lower right (magnification at $40 \times$ for each).

Immunohistochemical stains showed that the neoplastic lymphocytes were positive for CD20, PAX5, CD10, BCL2, and BCL6, with a Ki-67 index of $10 \%$ and minimal MYC expression. CD21 highlighted intact follicular dendritic cell meshworks throughout the section. The staging bone marrow biopsy showed paratrabecular aggregates of small lymphocytes, accounting for $40 \%$ of marrow cellularity. Flow cytometry of the marrow aspirate revealed that these cells were clonal, lambda-restricted $\mathrm{CD}^{-}, \mathrm{CD} 10(\text { var })^{+}, \mathrm{CD}_{1} 9^{+}, \mathrm{CD}_{20}{ }^{+}$, and $\mathrm{CD} 23^{+} \mathrm{B}$ cells, supporting the diagnosis of marrow involvement by FL.

The 2016 lymph node biopsy (see Fig. 2) showed a diffuse infiltrate consisting predominantly of large atypical lymphoid cells. Focally, macrophages with intracellular debris were noted, a finding indicative of high-grade malignancy with substantial cell death. The neoplastic cells were positive for PAX-5, CD79a, CD10, BCL2, MUM1, and, notably, TdT, with a Ki-67 index as high as $~ 80 \%$. In contrast to the 2015 biopsy, the neoplastic cells in 2016 were negative for CD20 and BCL6, but MYC staining was now positive in $70 \%$ of the neoplastic cells. Flow cytometry demonstrated that these malignant cells were positive for CD45 (dim), CD19, CD79a, CD10, and TdT, consistent with B-cell lymphoblasts. A tandem BM biopsy did not reveal lymphoma. However, in 2017 BM and peripheral blood displayed extensive involvement by the B-ALL/LBL.

\section{Analysis of SHM of Ig Genes}

To further characterize the FL and B-ALL/LBL, we performed NGS sequencing of Ig rearrangements from normal (reactive lymph node), $F L$, and $B-A L L / L B L$ specimens. In the $F L$, a single neoplastic clone (IgHV4-34_JH6) predominated, accounting for 99\% of the identified IgH rearranged clones (Supplemental Figs. 1 and 2). A considerable degree of SHM was evident in this clone, with a median of 130-139 mutated nucleotides per $1000 \mathrm{bp}$ (Fig. 3). This high level of SHM can be found in FLs (Gagyi et al. 2008; Wartenberg et al. 2013; Carlotti et al. 2015). 

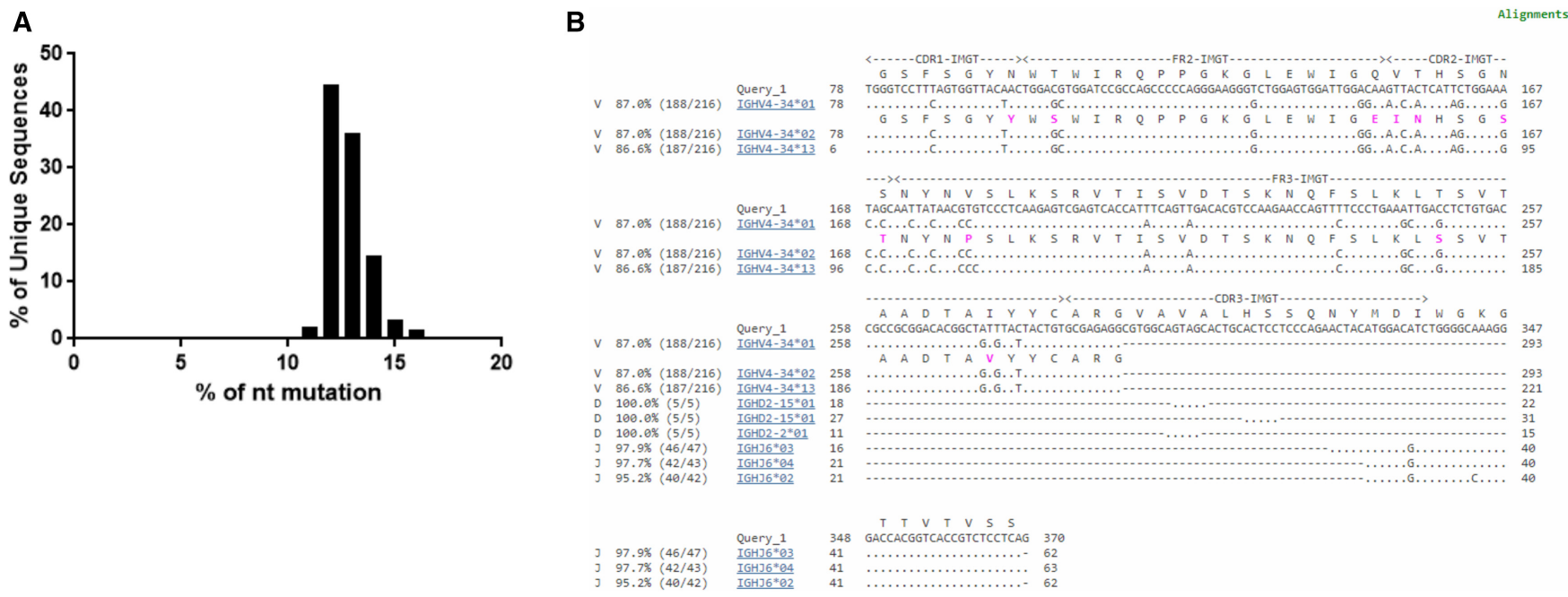

Figure 3. High levels of somatic hypermutation (SHM) in the heavy chain sequences of the dominant clone in the FL. (A) The percentage of unique heavy chain sequences of the clone is plotted versus the percentage of mutation in nucleotides from the germline. (B) IgBLAST alignment of highest copy IgH gene rearrangement in the dominant clone showing multiple mutations in both the nucleotide and amino acid sequence compared to the nearest germline $\mathrm{VH}$ gene, $\mathrm{VH} 4-34$.

When examining the heavy and light chain Ig gene rearrangements of the B-ALL/LBL, surprisingly no dominant clone was evident. Instead, a wide variety of different rearrangements were identified, spanning many $\mathrm{VH}$ and $\mathrm{JH}$ genes (Supplemental Figs. 1 and 2; Supplemental Tables 1 and 2). The sequence easily attributable to the IgVH4-34 clone seen in the $\mathrm{FL}$ accounted for $<1 \%$ of the rearrangements sequenced in the leukemia sample. Lambda light chain rearrangement analysis showed somewhat more identifiable overlap between the FL and B-ALL/LBL samples. Similar results were obtained using polymerase chain reaction (PCR)-based molecular studies for $\mathrm{lgH}$ gene rearrangement performed on the biopsies in the clinical laboratory. FL was positive for clonality with prominent peaks (Framework 2: 265/266-bp peaks) but B-ALL/LBL was negative and showed only a low amplitude of $\mathrm{lgH}$ amplification consistent with the lack of an identifiable dominant clone.

Given that the B-ALL/LBL clearly emerged from the FL as evidenced by the fluorescence in situ hybridization (FISH) and WES data (please see the paragraphs below), this lack of an identifiable dominant clone at the B-ALL/LBL stage likely stems from the extreme SHM upon the disease progression. SHM in advanced FL or, in particular, transformed to diffuse large B-cell lymphoma can be very extensive (Wartenberg et al. 2013; Carlotti et al. 2015), even involving non-lg gene loci (Pasqualucci et al. 2001; Rossi et al. 2006). Accordingly, lineage tracing of the dominant FL rearrangement in our case showed that some B-ALL/LBL clones were identified in distal portions and even in distinct branches of the FL lineage tree (Fig. 4). This pattern is consistent with the occurrence of "complex evolution" of the FL (Loeffler et al. 2015) with the relatedness between the lg clones in the FL and B-ALL/LBL being only partially traceable among the recovered (sequenced) Ig gene rearrangements.

\section{Karyotype and FISH Findings}

Although conventional cytogenetics showed a normal male karyotype 46,XY[20], FISH studies with gene break-apart probes performed on the $2015 \mathrm{FL}$-containing BM specimen were positive for rearrangements of BCL2 and BCL6 genes; the latter rearrangement is often associated with increased clinical aggressiveness of the disease (Akasaka et al. 2003). In 


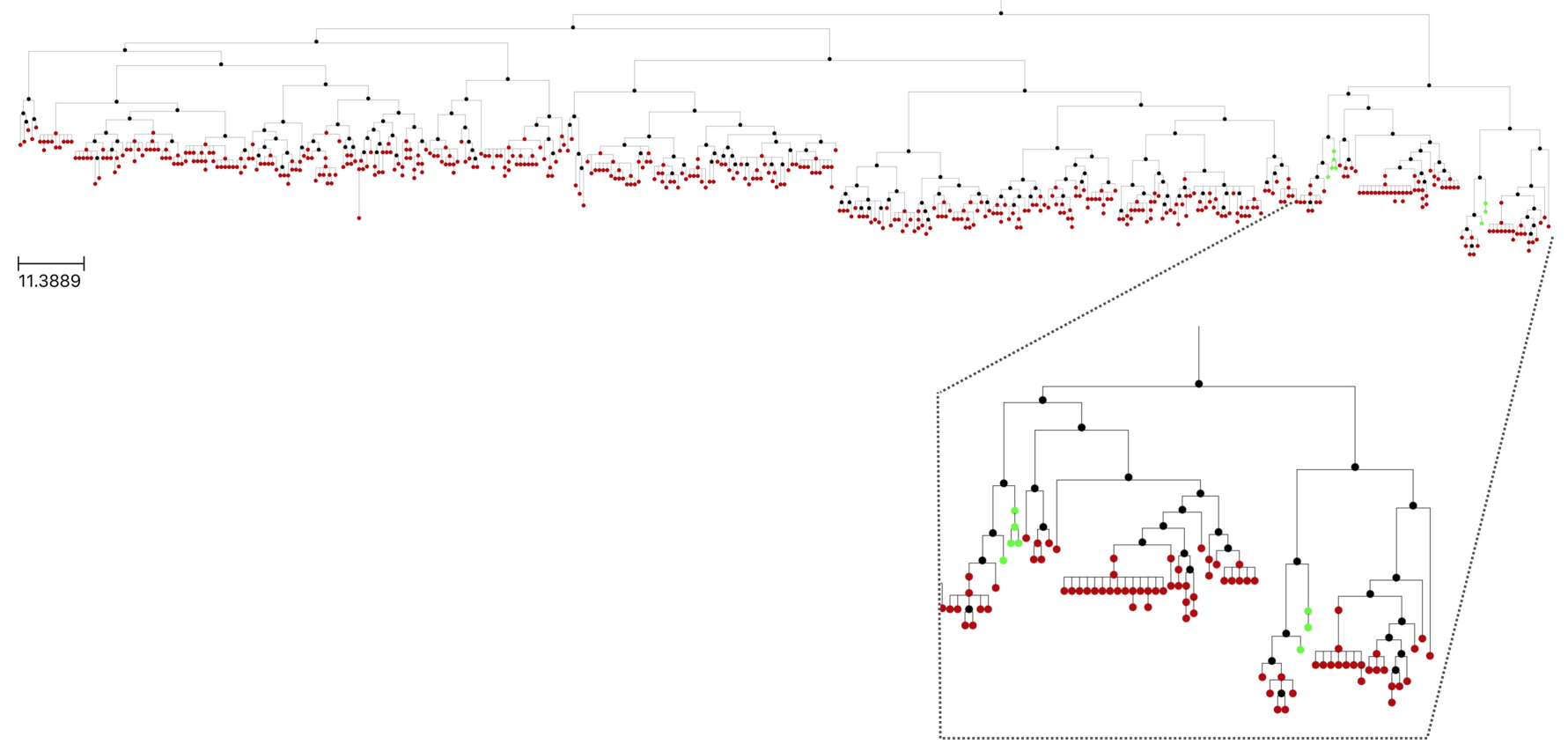

Figure 4. Lineage tree of the dominant FL clone. The dominant heavy chain gene rearrangement in the FL sample was tracked through lymph node samples from the FL and the B-ALL/LBL. A lineage tree structure was inferred as described in Methods. 5360 sequence copies are derived from the FL samples and 127 sequence copies are derived from the B-ALL/LBL sample. In the tree, black nodes are inferred, red nodes (located in the leaves of the tree) represent sequences in the FL, and green nodes represent sequences in the B-ALL/ LBL (inset). There are no nodes that are shared between the leukemia and lymphoma samples. Branch length (scale) is proportional to the number of mutations between a node and its parent.

contrast, no MYC gene rearrangement was identified at that time. Unexpectedly, FISH for IgH-BCL2 gene fusion was also negative, but sampling limitations or excessive tissue fixation may have diminished the sensitivity of detecting an $\mathrm{lgH}-B C L 2$ gene rearrangement in the lymph node.

FISH studies performed on the 2016 B-ALL/LBL-containing node biopsy were also positive for both BCL2 and BCL6 gene rearrangements as well as MYC gene rearrangement absent in FL. The rearrangement involving MYC, a potent oncogene, most likely played a key role in this transformation. MYC translocations are well-known to contribute to high aggressiveness of lymphomas and are a hallmark of FL-B-ALL/LBL transformation (Voorhees et al. 2004; Young et al. 2008; Geyer et al. 2015; Slot et al. 2016; Li et al. 2018). Interestingly, single-cell RNA-seq data in murine models have shown that MYC activity can predict reprogramming efficiency across many somatic cell types (Francesconi et al. 2019), emphasizing a potential element of "dedifferentiation" in these transformations.

Cytogenetic analysis of the 2017 bone marrow involved by B-ALL/LBL revealed a highly abnormal karyotype: 47,XY, $+X$, add(3)(q27), del(3)(q27), der(8), t(1;8)(q21;p23),t(8;14)(q24; $q 32), 14, \operatorname{ider}(14)(q 10) t(8 ; 14), \operatorname{dup}(17)(q 21 q 25),+18, \operatorname{der}(18), t(14 ; 18)(q 32 ; q 21)[20] / 46, X Y[4]$.

The simultaneous FISH studies were positive for BCL2, BCL6, and MYC gene rearrangements, but did identify a $t(14 ; 18)$ lgH-BCL2 translocation (because this was done in BM aspirate, the ability to detect $\operatorname{lgH}-B C L 2$ may have been higher as compared to the prior lymph node specimens). Overall, at least three different translocations were identified in this transformed, clinically advanced B-ALL/LBL with the $t(8: 14)$ involving the MYC gene occurring at this latter stage of the patient's lymphoma. 
COLD SPRING HARBOR Molecular Case Studies
Lymphoblastic transformation of follicular lymphoma

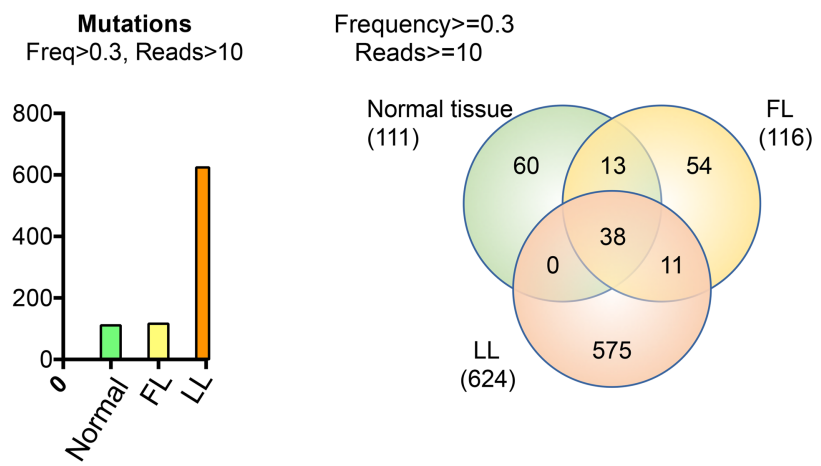

Figure 5. Number of variants by whole-exome sequencing (WES). The total number of single-nucleotide variants (SNVs) of each sample and the overlap of the SNVs between the samples is shown on the left and the right, respectively. Only variants that had an allele fraction $\geq 0.3$ and a read depth $\geq 10$ are included here.

\section{Genomic Sequencing Analyses}

Clinical next-generation sequencing analyses using a targeted hematologic malignancy panel of 54 genes were largely negative. No pathogenic variants were identified, and only a single variant of uncertain significance was identified in SETBP1 (p.V428M c.1282G > A) in the BM aspirate from 2017 involved by B-ALL/LBL. No variants were identified in the lymph node from 2016.

Next, an experimental comparative WES of the patient's normal tissue and the diagnostic biopsies from 2015 (FL) and 2016 (B-ALL/LBL) was performed in an attempt to better characterize the FL-B-ALL/LBL neoplastic progression scenario. We focused on mutations with high allelic frequencies (>30\%) to identify potential "drivers" of the disease and its progression. A total of 751 single-nucleotide variants (SNVs) were identified (Fig. 5). Normal tissue contained only a fraction (111) of such mutations including 13 shared with FL and 38 with both FL and B-ALL/LBL. In turn, FL contained a total of 116 mutations. In addition to the 51 shared with either normal or normal and B-ALL/LBL cells, FL also shared 11 mutations solely with B-ALL/LBL; this pattern further supports the FISH findings that the B-ALL/LBL indeed emerged from the underlying FL. Strikingly, the B-ALL/LBL acquired as many as 575 unique mutations at this posttransformation stage of the lymphoma.

\section{Characteristics of the Key Mutated Genes}

At least some of the mutations highlighted as potentially oncogenic (Table 1) may have contributed to disease development and transformation to B-ALL/LBL by dysregulating two main cellular functions: (1) epigenetic control of gene expression and its consequences, including pathways in histone methylation, transcription, chromatin structure, and cellular differentiation (KDM6A, KMT2D, SMARCA4, TAF3, and CBX1), and (2) DNA repair (JMY, TAF3, CBX1, KDM6A, and KMT2D). As noted, some of the mutations may affect both of these broadly defined key cell functions, and the associated cellular programs may sometimes, if not often, be intricately interwoven. Within this selected group of mutations, the TAF3 variant was the only one shared by normal and malignant cells and may have contributed to a predisposition for the development of $F L$ at an early age. In turn, the nonsense mutation in KMT2D was the only one identified in both $F L$ and B-ALL/LBL, perhaps contributing to the development of FL. The remaining mutations were all identified at the B-ALL/LBL stage only, indicating they might have played a role in driving the transformation to the aggressive lymphoblastic phase. 
Table 1. Molecular characteristics of the identified key potentially oncogenic mutations

\begin{tabular}{|c|c|c|c|c|c|c|c|c|c|}
\hline Gene & $\begin{array}{l}\text { Chromo- } \\
\text { some }\end{array}$ & $\begin{array}{l}\text { HGVS } \\
\text { DNA } \\
\text { reference }\end{array}$ & $\begin{array}{l}\text { HGVS } \\
\text { protein } \\
\text { reference }\end{array}$ & $\begin{array}{l}\text { Variant } \\
\text { type }\end{array}$ & $\begin{array}{l}\text { dbSNP/ } \\
\text { dbVar ID }\end{array}$ & $\begin{array}{c}\text { Genotype } \\
\text { (heterozygous/ } \\
\text { homozygous) }\end{array}$ & $\begin{array}{l}\text { Predicted } \\
\text { effect }\end{array}$ & $\begin{array}{c}\text { Allele } \\
\text { fraction (LL } \\
\text { only unless } \\
\text { otherwise } \\
\text { stated) }\end{array}$ & $\begin{array}{c}\text { Target } \\
\text { coverage } \\
\text { (LL only } \\
\text { unless } \\
\text { otherwise } \\
\text { stated) }\end{array}$ \\
\hline CBX1 & 17.46154253 & c. $114 \mathrm{G}>\mathrm{C}$ & p.Y38* & Nonsense & & Heterozygous & $\begin{array}{l}\text { Epigenetic } \\
\text { dysfunction, } \\
\text { DNA repair }\end{array}$ & 0.44 & 18 \\
\hline KDM6A & X.44820595 & c. $292 \mathrm{C}>\mathrm{T}$ & p.Q98* & Nonsense & & Heterozygous & $\begin{array}{l}\text { Epigenetic } \\
\text { dysfunction, } \\
\text { DNA repair }\end{array}$ & 0.4 & 30 \\
\hline SMARCA4 & 19.11132626 & $\begin{array}{c}\text { c. } 2842 \mathrm{G}> \\
\mathrm{A}\end{array}$ & p.A948T & Missense & & Heterozygous & $\begin{array}{l}\text { Dominant } \\
\text { negative, } \\
\text { epigenetic } \\
\text { dysfunction }\end{array}$ & 0.43 & 14 \\
\hline KMT2D & 12.49425446 & $\begin{array}{l}\text { c.13039_- } \\
13040 \mathrm{del}\end{array}$ & $\begin{array}{l}\text { p.Q4347 } \\
\text { Gfs*24 }\end{array}$ & Frameshift & & Heterozygous & $\begin{array}{l}\text { Epigenetic } \\
\text { dysfunction, } \\
\text { DNA repair }\end{array}$ & $\begin{array}{l}0.39(\mathrm{LL}) / \\
0.22(\mathrm{FL})\end{array}$ & $\begin{array}{l}56 \text { reads } \\
\quad(\mathrm{LL}) / 173 \\
\text { reads } \\
\text { (FL) }\end{array}$ \\
\hline$J M Y$ & 5.78610468 & $\begin{array}{l}\text { c. } 2453 C> \\
T\end{array}$ & p.P818L & Missense & $\begin{array}{l}\text { rs778673068, } \\
\text { COSM3618067, } \\
\text { COSM3618068 }\end{array}$ & Heterozygous & DNA repair & 0.5 & 12 \\
\hline TAF3 & 10.8007560 & $\begin{array}{l}\text { c. } 2087 T> \\
\text { A }\end{array}$ & p.V696E & Missense & & Heterozygous & $\begin{array}{l}\text { Epigenetic } \\
\text { dysfunction, } \\
\text { transcription } \\
\text { stress, DNA } \\
\text { repair }\end{array}$ & $\begin{array}{l}0.72(\mathrm{LL}) / \\
0.52(\mathrm{FL}) / \\
0.42 \\
\text { normal } \\
\text { tissue }\end{array}$ & $\begin{array}{l}129(\mathrm{LL}) / \\
148(\mathrm{FL}) / \\
86 \\
\text { normal } \\
\text { tissue }\end{array}$ \\
\hline
\end{tabular}

Dysregulation of Histone H3K27 Methylation and Cellular Differentiation (KDM6A)

Histone methyltransferases and demethylases are crucial for proper temporal regulation of gene expression and differentiation (Liu and Rando 2016). KDM6A (also known as UTX) functions as a histone H3K27 demethylase, removing the repressive H3K27 methylation mark to foster transcriptional gene activation (van Haaften et al. 2009). There is strong evidence that loss-of-function mutations in KDM6A, an established tumor-suppressor gene, play a role in cancer progression (Watanabe et al. 2018). Sequencing efforts of both hematologic and nonhematologic malignancies in humans support this notion (van Haaften et al. 2009; Van der Meulen et al. 2015; Waddell et al. 2015; Chakravarty et al. 2017; Gozdecka et al. 2018). Moreover, functional studies in model systems support the importance of KDM6A in regulating cellular differentiation (Lee et al. 2012; Faralli et al. 2016; OMIM for UTX 2018) and pluripotent stem cell formation (Schmidt and Plath 2012). Therefore, it is intriguing to hypothesize that loss of function of KDM6A contributed to dysregulated differentiation as this neoplasm evolved from FL to B-ALL/LBL, with "dedifferentiation" of malignant cells being the hallmark of this type of transformation (Young et al. 2008).

\section{Dysregulation of Histone H3K4 Methylation (KMT2D) and KMT2D/KDM6A Interplay}

A frameshift-based nonsense mutation was detected in KMT2D (MLL2), a H3K4 mono-methyltransferase that aids in the activation of gene expression and differentiation (OrtegaMolina et al. 2015; Rao and Dou 2015). KMT2D is one of the most frequently mutated genes 
COLD SPRING HARBOR Molecular Case Studies
Lymphoblastic transformation of follicular lymphoma in cancer, and loss-of-function mutations in this tumor suppressor are considered likely oncogenic drivers of B-cell lymphomas, FL in particular (Morin et al. 2011; Pasqualucci et al. 2011; Chakravarty et al. 2017). It has been suggested that KMT2D (MLL2) variants are late events in the evolution of FL (Green et al. 2013) and, hence, may have predisposed to B-ALL/LBL transformation in our case.

Of interest, trimethylations of histone $\mathrm{H} 3$ at lysine 4 (H3K4) and lysine 27 (H3K27) are typically associated with gene activation and silencing, respectively (Santos-Rosa et al. 2002; Ringrose et al. 2004; Simon and Kingston 2009). This histone trimethylation balance can even be altered in coordinated fashion to modulate transcriptional programs integral to cellular function and development (Azuara et al. 2006; Bernstein et al. 2006; Issaeva et al. 2007). Given the nonsense mutations of both KDM6A and KMT2D genes in our patient's lymphoma, functionality of H3K27 and H3K4 was likely strongly dysregulated.

\section{Dysregulation of Chromatin Structure (SMARCA4, CBX1)}

Another mutation of interest in this case is SMARCA4 A948T. SMARCA4 has a known role in cancer and has been typically considered a tumor suppressor gene, although there has been some recent debate of the exact role it plays in malignant cells (Chakravarty et al. 2017; Guerrero-Martínez and Reyes 2018). SMARCA4 functions in a SWI/SNF complex, regulating chromatin remodeling to control gene expression, perhaps requiring KDM6A (Miller et al. 2010).

The mutation identified in this patient falls in a span of an amino acid domain within which hotspot point mutations have been shown to induce a dominant negative effect (Hodges et al. 2018). Although SMARCA4 A948 is not one of the hotspot amino acids specifically examined in that study, residues nearby on both sides of A948 were shown to affect the DNA binding groove. Using published methods for modeling SMARCA4 structure using atomic coordinates (Hodges et al. 2018), we observe that the A948 residue also lies on an exposed surface residue in or near the DNA binding groove (data not shown). Because the A948T missense mutation replaces a hydrophobic residue with a polar residue, this change could also alter DNA binding. The A948T mutation is novel, and A948V mutation (a more conservative change than A948T) has been reported and is predicted to be pathogenic (Shihab et al. 2013; Tate et al. 2019).

Notably, SMARCA4 also interacts with MYC (Ewing et al. 2007). Given the lgH gene translocation-driven increase in MYC expression demonstrated in this patient's lymphoblastic lymphoma, it is reasonable to speculate that oncogenicity of the constitutively overexpressed MYC is even further perturbed by the mutated SMARCA4.

Another mutant that may dysregulate chromatin structure and gene expression is CBX1 p.Y38*. CBX1 (also referred to as HP1-Beta) encodes Chromobox protein homolog 1, a heterochromatic adaptor molecule implicated in both gene silencing and supranucleosomal chromatin structure (Lachner et al. 2001). Nonsense mutations of CBX1 have not been identified in the general population (Lek et al. 2016), and they have been only rarely seen in cancer thus far (Tate et al. 2019).

\section{Dysregulation of DNA Repair (JMY, KDM6A, KMT2D, and CBX1)}

The high mutation rate and chromosomal instability seen in B-ALL/LBL in this case may be due to defects in the transcriptional regulation of DNA repair pathways. The JMY P818L mutation may weaken DNA repair mechanisms. JMY functions as a transcriptional coactivator in the p53 pathway to respond to DNA damage (Adighibe and Pezzella 2018). The P818L missense mutation occurs in a proline-rich stretch of the protein (UniProt Consortium 2018) and is classified as likely pathogenic (Shihab et al. 2013). The P818L mutation has not been 
COLD SPRING HARBOR Molecular Case Studies
Lymphoblastic transformation of follicular lymphoma identified in healthy individuals (Lek et al. 2016) yet and has so far been noted in two cancer cases, albeit nonlymphoid (Tate et al. 2019).

In addition to their roles in cell differentiation, loss of function of KDM6A, KMT2D, and CBX1 have each been implicated in the DNA damage response and genome instability. KMT2D loss can lead to genomic instability via transcriptional stress (Kantidakis et al. 2016), heterozygous loss of CBX1 may be sufficient to cause dysfunction in the DNA damage response and lead to genomic instability (Aucott et al. 2008; Ayoub et al. 2008; White et al. 2013), and inhibition of KDM6A may affect DNA damage, specifically during vulnerable states of differentiation (Hofstetter et al. 2016). These findings suggest that the mutations identified in this study may affect DNA repair.

\section{Potential Germline Predisposition to Dysregulation of DNA Repair and Epigenetic Control of Cellular Function (TAF3)}

Finally, the TAF3 p.V696E mutant may alter the regulation of transcription, cell fate, pluripotency, and DNA repair (Pan and Thomson 2007; Jaenisch and Young 2008; Kungulovski et al. 2016; Liu and Rando 2016). Although, the mutation reported here is novel, it occurs at an amino acid position with common SNPs in the general population (e.g., rs10795583). It is important to note, however, that the common SNPs are conservative changes (p.V696L or p.V696A) that are not likely to have a large impact on protein function. On the other hand, p.V696E represents a nonconservative amino acid change that is more likely to impact function of TAF3. TFIID, the highly conserved transcription factor for RNA polymerase II, binds directly to H3K4me3 via TAF3, stimulating preinitiation complex formation (Vermeulen et al. 2007; Lauberth et al. 2013).

TAF3 functions at least in part through its interactions with H3K4 methylated histones, controlling the function of many transcription factors, including some that can induce pluripotency (Pan and Thomson 2007; Jaenisch and Young 2008; Kungulovski et al. 2016; Liu and Rando 2016). Moreover, the interaction of TAF3 and histones methylated at H3K4 may inhibit p53-dependent regulation of genes upon genotoxic insult (Bereczki et al. 2008; Lauberth et al. 2013). Because we identified the TAF3 V696E mutation in normal cells, and it was conserved in both FL and B-ALL/LBL, this potentially germline alteration might have predisposed to the lymphoma development by affecting the baseline of cellular differentiation programs or DNA repair.

\section{DISCUSSION}

We present here extensive molecular characterization of a rare clinical case of a 36-yr-old patient with a FL, which transformed into a B-lymphoblastic leukemia/lymphoma roughly $1 \mathrm{yr}$ after the initial diagnosis without any intervening medical treatment. The B-ALL/LBL transformation was ultimately followed by the patient's demise within the following year. This aggressive clinical course appears to be typical in the patients with FL-B-ALL/LBL progression (Geyer et al. 2015; Slot et al. 2016).

We identified a marked degree of SHM in the FL and it has been previously demonstrated that SHM increases during transformation from FL to DLBCL, starting from a known high baseline in FL (Loeffler et al. 2015). The SHM may have even "spilled over" to other gene loci, as reported previously in transformations to DLBCL (Pasqualucci et al. 2001; Rossi et al. 2006). Our findings suggest that FL to B-ALL/LBL transformation is associated with particularly robust SHM, rendering in our case most of the mutated immunoglobulin gene sequences virtually unrecognizable/unamplifiable by standard PCR primers and helping to explain why we could not identify the dominant malignant clone at the advanced, B-ALL/ 
LBL stage of the disease. Nevertheless, we did find some similarities between the highly SHM-changed Ig clones recovered in the FL and B-ALL/LBL, supporting the conclusion of high Ig mutational rate present at the B-ALL/LBL stage.

The clinical, cytogenetic, and WES data, together with the existing literature, clearly point toward the clonal relationship between FL and B-ALL/LBL in this patient. Not only did the B-ALL/LBL follow the FL within $1 \mathrm{yr}$ without any mutagenic therapy, but there were at least three pathogenic translocations, two of which (BCL2 and BCL6) overlapped between the FL and B-ALL/LBL. The addition of the MYC rearrangement matches all other cases of B-ALL/LBL transformed from FL (Geyer et al. 2015; Slot et al. 2016) and a clonal relationship between FL and B-ALL/LBL was established in all of these cases. Moreover, mechanistic roles for MYC in oncogenesis, genetic instability, aggressive transformations of lymphomas, and transdifferentiation have been previously demonstrated and further support this rearrangement as an important contributor to LL transformation (Okosun et al. 2014; Pasqualucci et al. 2014; Francesconi et al. 2019). WES analysis further indicates that B-ALL/LBL clonally emerged from the FL. FL and B-ALL/LBL shared 11 tumor-specific point mutations, and no point mutations were common to normal cells and $B-A L L / L B L$ but absent in FL, again supporting the scenario of $F L$ to $B-A L L / L B L$ progression.

It is important to note that this transformed B-ALL/LBL seems to be quite distinct from the "standard" de novo B-ALL/LBL. B-ALL/LBL transformed from FL is universally clinically more aggressive, with a unique molecular and genetic profile, including MYC gene translocation and, as we show, a much higher tumor mutational burden (TMB) than typically seen in de novo B-ALL/LBL (Liu et al. 2016; Chalmers et al. 2017). Therefore, it has suggested that transformed malignant tumors such as these be alternatively referred to as highgrade B-cell lymphoma with blastic features and TdT-expression (Ok et al. 2019). However, based on the progenitor B-cell phenotype and blastic morphology, we have chosen to call this case a transformation of FL to B-ALL/LBL, as typically done by others (Geyer et al. 2015; Slot et al. 2016) to follow the current WHO 2017 classification (Swerdlow et al. 2017).

Of note, even relative to the other two FL-B-ALL/LBL cases in which WES was performed, the "explosion" of point mutations (575) identified by us solely at the B-ALL/ LBL stage is remarkable (Geyer et al. 2015; Slot et al. 2016). This high mutational index suggests the possibility of impaired DNA repair mechanisms. In addition, several variants that may have dysregulated transcriptional programs and cellular differentiation were identified, at least to some degree by epigenetic dysregulation; the process is considered to play a key role in lymphomagenesis (Elenitoba-Johnson and Lim 2018). Given the additional aspect of "dedifferentiation" implied by this lymphoblastic transformation, mutations that affect these epigenetic pathways may be of particular importance in this context. Intriguingly, one of the two other published cases of a similar transformation in which WES was performed showed likely loss of function of both KMT2D and SMARCA2, a related protein to SMARCA4, albeit with unique features (Slot et al. 2016; Guerrero-Martínez and Reyes 2018). This may represent an overlapping mechanism in these transformations. However, given that KMT2D mutations are common in FL (Morin et al. 2011), the mutations may be associated with biological progression of FL in general, rather than B-ALL/ LBL transformation specifically.

Finally, the identified mutational profile may have potential implications for therapy of the FL-B-ALL/LBL transformation, which appears particularly difficult to treat. It is becoming increasingly evident that mutations in epigenetic modifier genes may be actionable. FLs often demonstrate pathogenic driver mutations in epigenetic modifier genes, such as KMT2D and EZH2, among others (Bödör et al. 2013; Okosun et al. 2016; Korfi et al. 2017; Weigert and Weinstock 2017). Our case study appears to align with that trend, and the combination of 
COLD SPRING HARBOR Molecular Case Studies
Lymphoblastic transformation of follicular lymphoma

mutations in epigenetic modifier genes suggests potential efficacy in therapeutics that target epigenetics, even at the B-ALL/LBL stage. Accordingly, loss-of-function mutations in KDM6A (H3K27me3 demethylase) seen in our case suggest inhibiting H3K27 methylation may prove therapeutically effective. Indeed, inhibitors of EZH2 (a H3K27me3 methyltransferase) show promise in clinical trials of advanced FL (Qi et al. 2012; Italiano et al. 2018). Interestingly, it has recently been shown that KDM6A loss can affect therapeutic response to EZH2 inhibitors in multiple myeloma and bladder cancer (Ezponda et al. 2017; Ler et al. 2017). Furthermore, given the presence of a potentially dominant negative SMARCA4 mutation, this therapeutic approach may have been particularly appropriate because EZH2 inhibitors may have more potent antitumor effects in some SMARCA4-deficient cancer models (Chan-Penebre et al. 2017).

In addition, HDAC inhibitors (HDACi) are another class of FDA-approved therapeutics targeting epigenetic modifiers. A mouse model of Kabuki syndrome, a congenital genetic disorder linked to loss of function of KMT2D or KDM6A, exhibited sensitivity to HDACi (Bjornsson et al. 2014). Because the B-ALL/LBL in this case demonstrated loss-of-function mutations in both of these genes associated with Kabuki syndrome, HDACi therapy may, perhaps, be considered in the future for B-ALL/LBL cases with similar mutations.

The potential therapeutic value of $\mathrm{H} 3 \mathrm{~K} 4 \mathrm{me} 3$ lysine demethylase inhibitors is also worth mentioning in the context of our mutational profile findings. Currently in development, these inhibitors have been reported to increase H3K4me3 levels with loss of function of KMT2D ( $\mathrm{H} 3 \mathrm{~K} 4 \mathrm{me} 3$ methyltransferase) and decrease cell proliferation in some cancer models (Korfi et al. 2017).

In summary, the combined findings reported here suggest a disease scenario in which transcriptional programs, cellular differentiation, and DNA repair mechanisms have been altered, perhaps in an interrelated fashion, leading to clonal "dedifferentiation" of a FL into a genetically unstable B-ALL/LBL. Therefore, the study provides new insights into the pathogenesis of FL-B-ALL/LBL transformation and suggests novel, disease biology-based therapeutic approaches to this aggressive and currently incurable disease.

\section{METHODS}

\section{Clinical Data}

All of the data was generated as a part of the routine clinical workup, including histology, immunohistochemistry, cytogenetics, FISH, and initial molecular genetic studies, which was performed in the anatomical and pathology laboratories at the Hospital of the University of Pennsylvania.

\section{Sample Preparation for Whole-Exome and Immunoglobulin Rearrangement Gene Sequencing Studies}

DNA was isolated from formalin-fixed paraffin-embedded lymph node tissue sections using the DNeasy Tissue kit (QIAGEN) and underwent WES analysis at the Children's Hospital of Philadelphia core facility served by Beijing Genomic Institute (BGI). A reactive lymph node without lymphoma obtained from the patient was used to represent normal tissue.

\section{Exome Sequencing, Alignment, and Variant Calling}

A whole-exome library was prepared using Agilent SureSelect Whole Exome v. 5 kit sequencing, which was performed on the Illumina HiSeq 4000. After removal of low-quality base and trimmed adapter sequences by Cutadapt, the unaligned reads in FASTO format were first 
COLD SPRING HARBOR Molecular Case Studies
Lymphoblastic transformation of follicular lymphoma

filtered by Bowtie 2 for contaminants and evaluated by pre-alignment $Q A / Q C$, then aligned to the hg19 reference genome using Bowtie 2, TopHat 2.0, and STAR. Using Partek Flow pipeline variants, aligned reads were called by SAMtools mpileup 1.4.1 on all samples, annotated with SnpEff, VEP, and Ensembl Transcripts 75, and confirmed using IGV and GoldenHelix sequence browsers. Variants were filtered by reads number (cut off at 10) and high allele fraction (cut off at 30\% for fixed essentially pure malignant cell populations). Mean coverage is $100 \times$. Benign SNPs and indels were excluded using ExAC/gnomAD databases if they were present at $>0.1 \%$ population frequency in either database (Lek et al. 2016).

\section{Evaluation of Variant Oncogenicity}

A combination of approaches was integrated to project the pathogenic potential of the variants. First, the biological function of the specific variant in cancer was assessed using the OncoKB database (Chakravarty et al. 2017). Then, the functionality of the variant protein was estimated based on the nature of the mutation (e.g., early stop codon = likely loss of function unless published data suggested otherwise) and the importance of the variant protein in cancer-related pathways, including review of protein domain mapping in UniProt and/ or PubMed. The abundance of the variant/nearby variants in cancer specimens in the COSMIC database (Tate et al. 2019) versus general population in ExAC/gnomAD (Lek et al. 2016) was also considered. Finally, some consideration was given to predictive algorithms (e.g., FATHMM, LoF score in ExAC) to help gauge the importance of protein and/ or variant (Shihab et al. 2013; Lek et al. 2016).

\section{Sequencing Analysis of Immunoglobulin Gene Rearrangements}

IgH: Immunoglobulin heavy-chain family-specific (framework region (FR)1 primers) PCRs were performed on genomic DNA samples as described previously (Meng et al. 2017), and sequencing was performed in the Human Immunology Core Facility at the University of Pennsylvania. Illumina $2 \times 300-b p$ paired-end kits were used for all experiments (Illumina MiSeq Reagent Kit v3, 600-cycle, Illumina MS-102-3003).

IgKappa and IgLambda: Sequencing was performed with adapted Biomed-2 primer series (van Dongen et al. 2003) and incorporated Illumina NexteraXT adapter sequences.

Kappa Light Chain Primers

NexteraXTR2-Hu-biomed2-Vk1f/6:

5'-GTCTCGTGGGCTCGGAGATGTGTATAAGAGACAGTCAAGGTTCAGCGGCA GTGGATCTG-3'

NexteraXTR2-Hu-biomed2-Vk2f:

5'-GTCTCGTGGGCTCGGAGATGTGTATAAGAGACAGGGCCTCCATCTCCTGCA GGTCTAGTC-3'

NexteraXTR2-Hu-biomed2-Vk3f:

5'-GTCTCGTGGGCTCGGAGATGTGTATAAGAGACAGCCCAGGCTCCTCATCTA TGATGCATCC-3'

NexteraXTR2-Hu-biomed2-Vk4:

5'-GTCTCGTGGGCTCGGAGATGTGTATAAGAGACAGCAACTGCAAGTCCAGCC AGAGTGTTTTT-3'

NexteraXTR2-Hu-biomed2-Vк5:

5'-GTCTCGTGGGCTCGGAGATGTGTATAAGAGACAGCCTGCAAAGCCAGCCA AGACATTGAT-3' 
COLD SPR ING HARB OR Molecular Case Studies
Lymphoblastic transformation of follicular lymphoma

NexteraXTR2-Hu-biomed2-Vк7:

5'-GTCTCGTGGGCTCGGAGATGTGTATAAGAGACAGGACCGATTTCACCCTCA CAATTAATCC-3'

NexteraXTR1-Hu-biomed2-Jk1-4:

5'-TCGTCGGCAGCGTCAGATGTGTATAAGAGACAGCTTACGTTTGATCTCCACC TTGGTCCC-3'

NexteraXTR1-Hu-biomed2-Jk5:

5'-TCGTCGGCAGCGTCAGATGTGTATAAGAGACAGANCTTACGTTTAATCTCCA GTCGTGTCCC-3'

Lambda Light Chain Primers

NexteraXTR2-Hu-biomed2-V入1/2:

5'-GTCTCGTGGGCTCGGAGATGTGTATAAGAGACAGATTCTCTGGCTCCAAGTCTGGC-3' NexteraXTR2-Hu-biomed2-V入3:

5'-GTCTCGTGGGCTCGGAGATGTGTATAAGAGACAGGGATCCCTGAGCGATTCTCTGG-3' NexteraXTR1-Hu-biomed2-J入1/2/3:

5'-TCGTCGGCAGCGTCAGATGTGTATAAGAGACAGCTAGGACGGTGAGCTTGGTCCC-3'

PCRs were performed on genomic DNA samples, and libraries were created under the same amplification and library preparation conditions as the $\mathrm{IgH}$ libraries.

\section{Data Analysis}

Repertoire sequencing data were analyzed using MiXCR (version 2.1.12), VDJtools (v1.1.10), and ImmuneDB as described in Bolotin et al. (2015); Shugay et al. (2015); Meng et al. (2017); and Rosenfeld et al. (2018). Sequences with at least two copies were included in all analyses. For the heavy chain lineage analysis, sequencing data were analyzed with ImmuneDB v0.28.0 using the default settings for $\mathrm{lgH}$ sequencing (Rosenfeld et al. 2018). Sequences with the same V-gene, J-gene, and CDR3 length having 85\% amino acid similarity in the CDR3 were clustered together as clones. For the dominant clone in the lymphoma sample (IgHV4-34, IgHJ6, CARGVAVALHSSQNYMDWW) ImmuneDB was used to infer a lineage from the sequences with at least two copies and ETE3 (Huerta-Cepas et al. 2016) was used to visualize the lineage tree structure in Figure 4.

\section{ADDITIONAL INFORMATION}

\section{Data Deposition and Access}

Consent to deposit genomic data in publicly accessible databases could not be obtained prior to the patient passing away. The WESs from normal cells, FL, and lymphoblastic lymphoma have been deposited in the NCBI BioSample database (https://www.ncbi.nlm .nih.gov/biosample/) under accession numbers SAMN13114138, SAMN13114139, and SAMN13114140.

\section{Ethics Statement}

Testing was done as part of routine clinical laboratory workup and Penn IRB \# 826234 protocol to study in-depth leftover diagnostic samples in hematopathology by novel 
COLD SPRING HARBOR Molecular Case Studies
Lymphoblastic transformation of follicular lymphoma
Competing Interest Statement

The authors have declared no competing interest.

\section{Referees}

Pedro Farinha

Anonymous

Received July 25, 2019; accepted in revised form October 16, 2019. techniques. The portion of the testing that was not clinically validated was not used to guide clinical care and did not interfere with clinical care.

\section{Acknowledgments}

We thank the Human Immunology Core facility at the University of Pennsylvania for their contributions to this work.

\section{Author Contributions}

The data were generated by W.M., H.Y.W., H.T.S., A.M.R., and Q.Z. and analyzed by all authors. The overall planning and the writing of the manuscript was done by J.P.B., E.T.L.P., and M.W.

\section{Funding}

This research was funded in part by the National Institutes of Health (NIH) grant P30CA016520, the Abramson Cancer Center Translational Center in Lymphoma, the Daniel B. Allanoff Foundation, and a Hematopathology Divisional Training grant.

\section{REFERENCES}

Adighibe O, Pezzella F. 2018. The role of JMY in p53 regulation. Cancers (Basel) 10: E173. doi:10.3390/ cancers10060173

Akasaka T, Lossos IS, Levy R. 2003. BCL6 gene translocation in follicular lymphoma: a harbinger of eventual transformation to diffuse aggressive lymphoma. Blood 102: 1443-1448. doi:10.1182/blood-2002-08-2482

Al-Tourah AJ, Gill KK, Chhanabhai M, Hoskins PJ, Klasa RJ, Savage KJ, Sehn LH, Shenkier TN, Gascoyne RD, Connors JM. 2008. Population-based analysis of incidence and outcome of transformed non-Hodgkin's lymphoma. J Clin Oncol 26: 5165-5169. doi:10.1200/JCO.2008.16.0283

Aucott R, Bullwinkel J, Yu Y, Shi W, Billur M, Brown JP, Menzel U, Kioussis D, Wang G, Reisert I, et al. 2008. HP1$\beta$ is required for development of the cerebral neocortex and neuromuscular junctions. J Cell Biol 183: 597606. doi:10.1083/jcb.200804041

Ayoub N, Jeyasekharan AD, Bernal JA, Venkitaraman AR. 2008. HP1- $\beta$ mobilization promotes chromatin changes that initiate the DNA damage response. Nature 453: 682-686. doi:10.1038/nature06875

Azuara V, Perry P, Sauer S, Spivakov M, Jørgensen HF, John RM, Gouti M, Casanova M, Warnes G, Merkenschlager M, et al. 2006. Chromatin signatures of pluripotent cell lines. Nat Cell Biol 8: 532-538. doi:10.1038/ncb1403

Bereczki O, Ujfaludi Z, Pardi N, Nagy Z, Tora L, Boros IM, Balint E. 2008. TATA binding protein associated factor 3 (TAF3) interacts with p53 and inhibits its function. BMC Mol Biol 9: 57. doi:10.1186/1471-21999-57

Bernstein BE, Mikkelsen TS, Xie X, Kamal M, Huebert DJ, Cuff J, Fry B, Meissner A, Wernig M, Plath K, et al. 2006. A bivalent chromatin structure marks key developmental genes in embryonic stem cells. Cell 125: 315-326. doi:10.1016/j.cell.2006.02.041

Bjornsson HT, Benjamin JS, Zhang L, Weissman J, Gerber EE, Chen YC, Vaurio RG, Potter MC, Hansen KD, Dietz HC. 2014. Histone deacetylase inhibition rescues structural and functional brain deficits in a mouse model of Kabuki syndrome. Sci Transl Med 6: 256ra135. doi:10.1126/scitranslmed.3009278

Bödör C, Grossmann V, Popov N, Okosun J, O'Riain C, Tan K, Marzec J, Araf S, Wang J, Lee AM, et al. 2013. EZH2 mutations are frequent and represent an early event in follicular lymphoma. Blood 122: 3165-3168. doi:10.1182/blood-2013-04-496893

Bolotin DA, Poslavsky S, Mitrophanov I, Shugay M, Mamedov IZ, Putintseva EV, Chudakov DM. 2015. MiXCR: software for comprehensive adaptive immunity profiling. Nat Methods 12: 380-381. doi:10.1038/nmeth .3364

Carlotti E, Wrench D, Rosignoli G, Marzec J, Sangaralingam A, Hazanov L, Michaeli M, Hallam S, Chaplin T, lqbal $S$, et al. 2015. High throughput sequencing analysis of the immunoglobulin heavy chain gene from flow-sorted B cell sub-populations define the dynamics of follicular lymphoma clonal evolution. PLoS One 10: e0134833. doi:10.1371/journal.pone.0134833 
Chakravarty D, Gao J, Phillips SM, Kundra R, Zhang H, Wang J, Rudolph JE, Yaeger R, Soumerai T, Nissan MH, et al. 2017. OncoKB: a precision oncology knowledge base. JCO Precis Oncol 2017. doi:10.1200/PO.17 .00011

Chalmers ZR, Connelly CF, Fabrizio D, Gay L, Ali SM, Ennis R, Schrock A, Campbell B, Shlien A, Chmielecki J, et al. 2017. Analysis of 100,000 human cancer genomes reveals the landscape of tumor mutational burden. Genome Med 9: 34. doi:10.1186/s13073-017-0424-2

Chan-Penebre E, Armstrong K, Drew A, Grassian AR, Feldman I, Knutson SK, Kuplast-Barr K, Roche M, Campbell J, Ho P, et al. 2017. Selective killing of SMARCA2- and SMARCA4-deficient small cell carcinoma of the ovary, hypercalcemic type cells by inhibition of EZH2: in vitro and in vivo preclinical models. Mol Cancer Ther 16: 850-860. doi:10.1158/1535-7163.MCT-16-0678

De Jong D, Voetdijk BM, Beverstock GC, van Ommen GJ, Willemze R, Kluin PM. 1988. Activation of the c-myc oncogene in a precursor-B-cell blast crisis of follicular lymphoma, presenting as composite lymphoma. $N$ Engl J Med 318: 1373-1378. doi:10.1056/NEJM198805263182106

Elenitoba-Johnson KSJ, Lim MS. 2018. New insights into lymphoma pathogenesis. Annu Rev Pathol 13: 193217. doi:10.1146/annurev-pathol-020117-043803

Ewing RM, Chu P, Elisma F, Li H, Taylor P, Climie S, McBroom-Cerajewski L, Robinson MD, O'Connor L, Li M, et al. 2007. Large-scale mapping of human protein-protein interactions by mass spectrometry. Mol Syst Biol 3: 89. doi:10.1038/msb4100134

Ezponda T, Dupéré-Richer D, Will CM, Small EC, Varghese N, Patel T, Nabet B, Popovic R, Oyer J, Bulic M, et al. 2017. UTX/KDM6A loss enhances the malignant phenotype of multiple myeloma and sensitizes cells to EZH2 inhibition. Cell Rep 21: 628-640. doi:10.1016/j.celrep.2017.09.078

Faralli H, Wang C, Nakka K, Benyoucef A, Sebastian S, Zhuang L, Chu A, Palii CG, Liu C, Camellato B, et al. 2016. UTX demethylase activity is required for satellite cell-mediated muscle regeneration. J Clin Invest 126: 1555-1565. doi:10.1172/JCl83239

Francesconi M, Di Stefano B, Berenguer C, de Andrés-Aguayo L, Plana-Carmona M, Mendez-Lago M, Guillaumet-Adkins A, Rodriguez-Esteban G, Gut M, Gut IG, et al. 2019. Single cell RNA-seq identifies the origins of heterogeneity in efficient cell transdifferentiation and reprogramming. Elife 8: e41267. doi:10.7554/eLife.41627

Gagyi E, Balogh Z, Bödör C, Timár B, Reiniger L, Deák L, Csomor J, Csernus B, Szepesi B, Matolcsy A. 2008. Somatic hypermutation of IGVH genes and aberrant somatic hypermutation in follicular lymphoma without BCL2 gene rearrangement and expression. Haematologica 93: 1822-1828.

Gauwerky CE, Hoxie J, Nowell PC, Croce CM. 1988. Pre-B-cell leukemia with a $t(8 ; 14)$ and a $t(14 ; 18)$ translocation is preceded by follicular lymphoma. Oncogene 2: 431-435.

Geyer JT, Subramaniyam S, Jiang Y, Elemento O, Ferry JA, de Leval L, Nakashima MO, Liu YC, Martin P, Mathew S, et al. 2015. Lymphoblastic transformation of follicular lymphoma: a clinicopathologic and molecular analysis of 7 patients. Hum Pathol 46: 260-271. doi:10.1016/j.humpath.2014 .10 .021

Gozdecka M, Meduri E, Mazan M, Tzelepis K, Dudek M, Knights AJ, Pardo M, Yu L, Choudhary JS, Metzakopian E, et al. 2018. UTX-mediated enhancer and chromatin remodeling suppresses myeloid leukemogenesis through noncatalytic inverse regulation of ETS and GATA programs. Nat Genet 50: 883-894. doi:10.1038/s41588-018-0114-z

Green MR, Gentles AJ, Nair RV, Irish JM, Kihira S, Liu CL, Kela I, Hopmans ES, Myklebust JH, Ji H, et al. 2013. Hierarchy in somatic mutations arising during genomic evolution and progression of follicular lymphoma. Blood 121: 1604-1611. doi:10.1182/blood-2012-09-457283

Guerrero-Martínez JA, Reyes JC. 2018. High expression of SMARCA4 or SMARCA2 is frequently associated with an opposite prognosis in cancer. Sci Rep 8: 2043. doi:10.1038/s41598-018-20217-3

Hodges HC, Stanton BZ, Cermakova K, Chang CY, Miller EL, Kirkland JG, Ku WL, Veverka V, Zhao K, Crabtree GR. 2018. Dominant-negative SMARCA4 mutants alter the accessibility landscape of tissue-unrestricted enhancers. Nat Struct Mol Biol 25: 61-72. doi:10.1038/s41594-017-0007-3

Hofstetter C, Kampka JM, Huppertz S, Weber H, Schlosser A, Müller AM, Becker M. 2016. Inhibition of KDM6 activity during murine ESC differentiation induces DNA damage. J Cell Sci 129: 788-803. doi:10.1242/jcs .175174

Huerta-Cepas J, Serra F, Bork P. 2016. ETE 3: reconstruction, analysis and visualization of phylogenomic data. Mol. Biol. Evol 33: 1635-1638. doi:10.1093/molbev/msw046

Issaeva I, Zonis Y, Rozovskaia T, Orlovsky K, Croce CM, Nakamura T, Mazo A, Eisenbach L, Canaani E. 2007. Knockdown of ALR (MLL2) reveals ALR target genes and leads to alterations in cell adhesion and growth. Mol Cell Biol 27: 1889-1903. doi:10.1128/MCB.01506-06

Italiano A, Soria JC, Toulmonde M, Michot JM, Lucchesi C, Varga A, Coindre JM, Blakemore SJ, Clawson A, Suttle B, et al. 2018. Tazemetostat, an EZH2 inhibitor, in relapsed or refractory B-cell non-Hodgkin lymphoma and advanced solid tumours: a first-in-human, open-label, phase 1 study. Lancet Oncol 19: 649-659. doi:10.1016/S1470-2045(18)30145-1 
Jaenisch R, Young R. 2008. Stem cells, the molecular circuitry of pluripotency and nuclear reprogramming. Cell 132: 567-582. doi:10.1016/j.cell.2008.01.015

Kantidakis T, Saponaro M, Mitter R, Horswell S, Kranz A, Boeing S, Aygün O, Kelly GP, Matthews N, Stewart A, et al. 2016. Mutation of cancer driver MLL2 results in transcription stress and genome instability. Genes Dev 30: 408-420. doi:10.1101/gad.275453.115

Korfi K, Ali S, Heward JA, Fitzgibbon J. 2017. Follicular lymphoma, a B cell malignancy addicted to epigenetic mutations. Epigenetics 12: 370-377. doi:10.1080/15592294.2017.1282587

Kroft SH, Domiati-Saad R, Finn WG, Dawson DB, Schnitzer B, Singleton TP, Ross CW. 2000. Precursor B-lymphoblastic transformation of grade I follicle center lymphoma. Am J Clin Pathol 113: 411-418. doi:10 .1309/Y2YD-UNA2-C95R-AVM3

Kungulovski G, Mauser R, Reinhardt R, Jeltsch A. 2016. Application of recombinant TAF3 PHD domain instead of anti-H3K4me3 antibody. Epigenetics Chromatin 9: 11. doi:10.1186/s13072-016-0061-9

Lachner M, O'Carroll D, Rea S, Mechtler K, Jenuwein T. 2001. Methylation of histone H3 lysine 9 creates a binding site for HP1 proteins. Nature 410: 116-120. doi:10.1038/35065132

Lauberth SM, Nakayama T, Wu X, Ferris AL, Tang Z, Hughes SH, Roeder RG. 2013. H3K4me3 interactions with TAF3 regulate preinitiation complex assembly and selective gene activation. Cell 152: 1021-1036. doi:10 .1016/j.cell.2013.01.052

Lee S, Lee JW, Lee SK. 2012. UTX, a histone H3-lysine 27 demethylase, acts as a critical switch to activate the cardiac developmental program. Dev Cell 22: 25-37. doi:10.1016/j.devcel.2011.11.009

Lek M, Karczewski KJ, Minikel EV, Samocha KE, Banks E, Fennell T, O'Donnell-Luria AH, Ware JS, Hill AJ, Cummings BB, et al. 2016. Analysis of protein-coding genetic variation in 60,706 humans. Nature 536: 285-291. doi:10.1038/nature19057

Ler LD, Ghosh S, Chai X, Thike AA, Heng HL, Siew EY, Dey S, Koh LK, Lim JQ, Lim WK, et al. 2017. Loss of tumor suppressor KDM6A amplifies PRC2-regulated transcriptional repression in bladder cancer and can be targeted through inhibition of EZH2. Sci Transl Med 9: eaai8312. doi:10.1126/scitranslmed .aai8312

LiY, Gupta G, Molofsky A, Xie Y, Shihabi N, McCormick J, Jaffe ES. 2018. B lymphoblastic leukemia/lymphoma with Burkitt-like morphology and IGH/MYC rearrangement: report of 3 cases in adult patients. Am J Surg Pathol 42: 269-276. doi:10.1097/PAS.0000000000000982

Liu L, Rando TA. 2016. UTX in muscle regeneration—the right dose and the right time. J Clin Invest 126: 12331235. doi:10.1172/JCl86798

Liu YF, Wang BY, Zhang WN, Huang JY, Li BS, Zhang M, Jiang L, Li JF, Wang MJ, Dai YJ, et al. 2016. Genomic profiling of adult and pediatric B-cell acute lymphoblastic leukemia. EBioMedicine 8: 173-183. doi:10 .1016/j.ebiom.2016.04.038

Loeffler M, Kreuz M, Haake A, Hasenclever D, Trautmann H, Arnold C, Winter K, Koch K, Klapper W, Scholtysik $\mathrm{R}$, et al. 2015. Genomic and epigenomic co-evolution in follicular lymphomas. Leukemia 29: 456-463. doi:10.1038/leu.2014.209

Meng W, Zhang B, Schwartz GW, Rosenfeld AM, Ren D, Thome JJC, Carpenter DJ, Matsuoka N, Lerner H, Friedman AL, et al. 2017. An atlas of B-cell clonal distribution in the human body. Nat Biotechnol 35: 879-884. doi:10.1038/nbt.3942

Miller SA, Mohn SE, Weinmann AS. 2010. Jmjd3 and UTX play a demethylase-independent role in chromatin remodeling to regulate T-box family member-dependent gene expression. Mol Cell 40: 594-605. doi:10 .1016/j.molcel.2010.10.028

Montoto S, Fitzgibbon J. 2011. Transformation of indolent B-cell lymphomas. J Clin Oncol 29: 1827-1834. doi:10.1200/JCO.2010.32.7577

Morin RD, Mendez-Lago M, Mungall AJ, Goya R, Mungall KL, Corbett RD, Johnson NA, Severson TM, Chiu R, Field $M$, et al. 2011. Frequent mutation of histone-modifying genes in non-Hodgkin lymphoma. Nature 476: 298-303. doi:10.1038/nature10351

Ok CY, Madeiros LJ, Thakral B, Tang G, Jain N, Jabbour E, Pierce SA, Konoplev S. 2019. High-grade B-cell lymphomas with TdT expression: a diagnostic and classification dilemma. Mod Pathol 32: 48-58. doi:10 .1038/s41379-018-0112-9

Okosun J, Bödör C, Wang J, Araf S, Yang CY, Pan C, Boller S, Cittaro D, Bozek M, lqbal S, et al. 2014. Integrated genomic analysis identifies recurrent mutations and evolution patterns driving the initiation and progression of follicular lymphoma. Nat Genet 46: 176-181. doi:10.1038/ng.2856

Okosun J, Montoto S, Fitzgibbon J. 2016. The routes for transformation of follicular lymphoma. Curr Opin Hematol 23: 385-391. doi:10.1097/MOH.0000000000000255

OMIM. 2018. Online Mendelian Inheritance in Man, OMIM ${ }^{\circledR}$. Johns Hopkins University, Baltimore, MD.

Ortega-Molina A, Boss IW, Canela A, Pan H, Jiang Y, Zhao C, Jiang M, Hu D, Agirre X, Niesvizky I, et al. 2015. The histone lysine methyltransferase KMT2D sustains a gene expression program that represses $B$ cell lymphoma development. Nat Med 21: 1199-1208. doi:10.1038/nm.3943 
Pan G, Thomson JA. 2007. Nanog and transcriptional networks in embryonic stem cell pluripotency. Cell Res 17: 42-49. doi:10.1038/sj.cr.7310125

Pasqualucci L, Neumeister P, Goossens T, Nanjangud G, Chaganti RS, Küppers R, Dalla-Favera R. 2001. Hypermutation of multiple proto-oncogenes in B-cell diffuse large-cell lymphomas. Nature 412: $341-$ 346. doi:10.1038/35085588

Pasqualucci L, Trifonov V, Fabbri G, Ma J, Rossi D, Chiarenza A, Wells VA, Grunn A, Messina M, Elliot O, et al. 2011. Analysis of the coding genome of diffuse large B-cell lymphoma. Nat Genet 43: 830-837. doi:10 $.1038 / \mathrm{ng} .892$

Pasqualucci L, Khiabanian H, Fangazio M, Vasishtha M, Messina M, Holmes AB, Ouillette P, Trifonov V, Rossi D, Tabbò F, et al. 2014. Genetics of follicular lymphoma transformation. Cell Rep 6: 130-140. doi:10.1016/j .celrep.2013.12.027

Qi W, Chan H, Teng L, Li L, Chuai S, Zhang R, Zeng J, Li M, Fan H, Lin Y, et al. 2012. Selective inhibition of Ezh2 by a small molecule inhibitor blocks tumor cells proliferation. Proc Natl Acad Sci 109: 21360-21365. doi:10 .1073/pnas.1210371110

Rao RC, Dou Y. 2015. Hijacked in cancer: the KMT2 (MLL) family of methyltransferases. Nat Rev Cancer 15: 334-346. doi:10.1038/nrc3929

Ringrose L, Ehret H, Paro R. 2004. Distinct contributions of histone H3 lysine 9 and 27 methylation to locusspecific stability of polycomb complexes. Mol Cell 16: 641-653. doi:10.1016/j.molcel.2004.10.015

Rosenfeld AM, Meng W, Luning Prak ET, Hershberg U. 2018. ImmuneDB, a novel tool for the analysis, storage, and dissemination of immune repertoire sequencing Data. Front Immunol 21: 2107. doi:10.3389/fimmu 2018.02107

Rossi D, Berra E, Cerri M, Deambrogi C, Barbieri C, Franceschetti S, Lunghi M, Conconi A, Paulli M, Matolcsy A, et al. 2006. Aberrant somatic hypermutation in transformation of follicular lymphoma and chronic lymphocytic leukemia to diffuse large B-cell lymphoma. Haematologica 91: 1405-1409.

Santos-Rosa H, Schneider R, Bannister AJ, Sherriff J, Bernstein BE, Emre NC, Schreiber SL, Mellor J, Kouzarides T. 2002. Active genes are tri-methylated at K4 of histone H3. Nature 419: 407-411. doi:10.1038/ nature 01080

Schmidt R, Plath K. 2012. The roles of the reprogramming factors Oct4, Sox2 and Klf4 in resetting the somatic cell epigenome during induced pluripotent stem cell generation. Genome Biol 13: 251. doi:10.1186/gb2012-13-10-251

Shihab HA, Gough J, Cooper DN, Day IN, Gaunt TR. 2013. Predicting the functional consequences of cancer-associated amino acid substitutions. Bioinformatics 29: 1504-1510. doi:10.1093/bioinformatics/ btt182

Shugay M, Bagaev DV, Turchaninova MA, Bolotin DA, Britanova OV, Putintseva EV, Pogorelyy MV, Nazarov VI, Zvyagin IV, Kirgizova VI, et al. 2015. VDJtools: unifying post-analysis of T cell receptor repertoires. PLoS Comput Biol 11: e1004503. doi:10.1371/journal.pcbi.1004503

Simon JA, Kingston RE. 2009. Mechanisms of Polycomb gene silencing: knowns and unknowns. Nat Rev Mol Cell Biol 10: 697-708. doi:10.1038/nrm2763

Slot LM, Hoogeboom R, Smit LA, Wormhoudt TA, Biemond BJ, Oud ME, Schilder-Tol EJ, Mulder AB, Jongejan A, van Kampen AH, et al. 2016. B-lymphoblastic lymphomas evolving from follicular lymphomas co-express surrogate light chains and mutated $\gamma$ heavy chains. Am J Pathol 186: 3273-3284. doi:10.1016/j .ajpath.2016.07.027

Sun X, Gordon LI, Peterson LC. 2002. Transformation of follicular lymphoma to acute lymphoblastic leukemia. Arch Pathol Lab Med 126: 997-998.

Swerdlow SH, Campo E, Harris NL, Jaffe ES, Pileri SA, Stein H, Thiele J. 2017. WHO classification of tumours of haematopoietic and lymphoid tissues, Revised 4th ed. The International Agency for Research on Cancer, Lyon, France.

Tate JG, Bamford S, Jubb HC, Sondka Z, Beare DM, Bindal N, Boutselakis H, Cole CG, Creatore C, Dawson E, et al. 2019. COSMIC: the Catalogue Of Somatic Mutations In Cancer. Nucleic Acids Res 47: D941-D947. doi:10.1093/nar/gky1015

UniProt Consortium T. 2018. UniProt: the universal protein knowledgebase. Nucleic Acids Res 46: 2699. doi:10.1093/nar/gky092

Van der Meulen J, Sanghvi V, Mavrakis K, Durinck K, Fang F, Matthijssens F, Rondou P, Rosen M, Pieters T, Vandenberghe $P$, et al. 2015. The H3K27me3 demethylase UTX is a gender-specific tumor suppressor in T-cell acute lymphoblastic leukemia. Blood 125: 13-21. doi:10.1182/blood-2014-05577270

van Dongen JJ, Langerak AW, Brüggemann M, Evans PA, Hummel M, Lavender FL, Delabesse E, Davi F, Schuuring E, García-Sanz R, et al. 2003. Design and standardization of PCR primers and protocols for detection of clonal immunoglobulin and T-cell receptor gene recombinations in suspect lymphoproliferations: report of the BIOMED-2 Concerted Action BMH4-CT98-3936. Leukemia 17: 2257-2317. doi:10.1038/sj .leu.2403202 
COLD SPRING HARB OR Molecular Case Studies
Lymphoblastic transformation of follicular lymphoma

van Haaften G, Dalgliesh GL, Davies H, Chen L, Bignell G, Greenman C, Edkins S, Hardy C, O'Meara S, Teague $\mathrm{J}$, et al. 2009. Somatic mutations of the histone H3K27 demethylase gene UTX in human cancer. Nat Genet 41: 521-523. doi:10.1038/ng.349

Vermeulen M, Mulder KW, Denissov S, Pijnappel WW, van Schaik FM, Varier RA, Baltissen MP, Stunnenberg HG, Mann M, Timmers HT. 2007. Selective anchoring of TFIID to nucleosomes by trimethylation of histone H3 lysine 4. Cell 131: 58-69. doi:10.1016/j.cell.2007.08.016

Voorhees PM, Carder KA, Smith SV, Ayscue LH, Rao KW, Dunphy CH. 2004. Follicular lymphoma with a Burkitt translocation-predictor of an aggressive clinical course: a case report and review of the literature. Arch Pathol Lab Med 128: 210-213.

Waddell N, Pajic M, Patch AM, Chang DK, Kassahn KS, Bailey P, Johns AL, Miller D, Nones K, Quek K, et al. 2015. Whole genomes redefine the mutational landscape of pancreatic cancer. Nature 518: 495-501. doi:10.1038/nature14169

Wartenberg M, Vasil P, zum Bueschenfelde CM, Ott G, Rosenwald A, Fend F, Kremer M. 2013. Somatic hypermutation analysis in follicular lymphoma provides evidence suggesting bidirectional cell migration between lymph node and bone marrow during disease progression and relapse. Haematologica 98: 1433-1441. doi:10.3324/haematol.2012.074252

Watanabe S, Shimada S, Akiyama Y, Ishikawa Y, Ogura T, Ogawa K, Ono H, Mitsunori Y, Ban D, Kudo A, et al. 2018. Loss of KDM6A characterizes a poor prognostic subtype of human pancreatic cancer and potentiates HDAC inhibitor lethality. Int J Cancer 145: 192-205. doi:10.1002/ijc.32072

Weigert O, Weinstock DM. 2017. The promises and challenges of using gene mutations for patient stratification in follicular lymphoma. Blood 130: 1491-1498. doi:10.1182/blood-2017-07-737353

White JK, Gerdin AK, Karp NA, Ryder E, Buljan M, Bussell JN, Salisbury J, Clare S, Ingham NJ, Podrini C, et al. 2013. Genome-wide generation and systematic phenotyping of knockout mice reveals new roles for many genes. Cell 154: 452-464. doi:10.1016/j.cell.2013.06.022

Young KH, Xie Q, Zhou G, Eickhoff JC, Sanger WG, Aoun P, Chan WC. 2008. Transformation of follicular lymphoma to precursor B-cell lymphoblastic lymphoma with c-myc gene rearrangement as a critical event. Am J Clin Pathol 129: 157-166. doi:10.1309/NKK3FEX2BE5L7EKB 


\section{COLD SPRING HARBOR Molecular Case Studies}

\section{Dramatic increase in gene mutational burden after transformation of follicular lymphoma into TdT + B-lymphoblastic leukemia/lymphoma}

Jonathan P. Belman, Wenzhao Meng, Hong Yi Wang, et al.

Cold Spring Harb Mol Case Stud 2020, 6: a004614 originally published online November 27, 2019 Access the most recent version at doi: $10.1101 / \mathrm{mcs} .0004614$

\section{Supplementary http://molecularcasestudies.cshlp.org/content/suppl/2019/12/12/mcs.a004614.D Material $\quad$ C1 \\ References This article cites 83 articles, 19 of which can be accessed free at: http://molecularcasestudies.cshlp.org/content/6/1/a004614.full.html\#ref-list-1 \\ License This article is distributed under the terms of the Creative Commons Attribution-NonCommercial License, which permits reuse and redistribution, except for commercial purposes, provided that the original author and source are credited. \\ Email Alerting Receive free email alerts when new articles cite this article - sign up in the box at the Service top right corner of the article or click here.}

